\title{
PENGARUH KULIAH MELALUI WHATSAPPS TERHADAP KEPUASAAN MAHASISWA D3 MANAJEMEN PAJAK UNIVERSITAS BINA SARANA INFORMATIKA (UBSI) CABANG SALEMBA 22 JAKARTA
}

\author{
Jaka Santosa $^{1}$, Eulin Karlina ${ }^{2}$, Panji Suratriadi ${ }^{3}$ \\ ${ }^{123}$ Universitas Bina Sarana Informatika \\ suratriadi@gmail.com
}

\begin{abstract}
The spread of the Covid-19 in Jakarta affected the educational activities carried out through the internet media. Utilization of the internet with the Whatsapp application is one of the applications used for lecture activities by students. The results of our study that the magnitude of the coefficient of determination $\left(\mathrm{R}^{2}\right)$ of 0.89 means that the influence of the Trust variable is very strong on the dependent variable (participation), so we say Lecture via Whatsapps affects Student Satisfaction of $89.0 \%$. From the coefficients table obtained a simple regression equation $\mathrm{Y}=0.393 \mathrm{X}+38.98$, meaning that if there are no lectures through Whatsapps there is still student satisfaction of 38.981. And each addition of one unit of lecture via Whatsapps then increases student satisfaction by 0.393 . Another $11 \%$ factor that affects student satisfaction is the time factor of learning interaction in terms of student questions and answers to lecturers can be done 24 hours, and also factors of signal or adequate internet network and increasingly sophisticated smartphone types.
\end{abstract}

Keyword: Lectures via Whatsapps, Student satisfaction

\begin{abstract}
Abstrak: Penyebaran wabah Covid-19 di Jakarta berdampak pada kegiatan pendidikan yang dilakukan melalui media internet. Pemanfaatan internet dengan aplikasi Whatsapp adalah salah satu aplikasi yang digunakan untuk kegiatan perkuliahan oleh mahasiswa. Hasil dari peneltian kami bahwa besarnya koefisien determinasi $\left(\mathrm{R}^{2}\right)$ sebesar 0,89 artinya pengaruh variabel Trust sangat kuat terhadap variabel terikat (partisipasi), sehingga kita katakan Kuliah melalu Whatsapps mempengaruhi Kepuasaan Mahasiswa sebesar 89,0\%. Dari tabel coefficients didapat persamaan regresi sederhana $\mathrm{Y}=0,393 \mathrm{X}+38,98$, artinya apabila tidak ada kuliah melalui Whatsapps maka masih ada kepuasaan mahasiswa sebesar 38,981. Dan Setiap penambahan satu satuan kuliah melalui Whatsapps maka menambah kepuasaan mahasiswa sebesar 0,393. Faktor lain 11\% yang mempengaruhi kepuasaan mahasiswa adalah faktor waktu interaksi belajar dalam hal tanya jawab mahasiswa kepada dosennya dapat dilakukan 24 jam, dan juga faktor sinyal atau jaringan internet yang memadai serta tipe smartphone yang semakin canggih.
\end{abstract}

Keyword: Kuliah melalui Whatsapps, Kepuasaan mahasiswa 


\section{Pendahuluan}

Merebaknya wabah virus Corona Covid-19 terutama di Jakarta turut berimbas pada kegiatan pendidikan, dengan dikeluarkan kebijakan Pembelajaran Jarak Jauh (PJJ) oleh Kementerian Pendidikan dan Kebudayaan yang tertuang dalam Surat Edaran No.3 tahun 2020. Tujuannya adalah mencegah perkembangan dan penyebaran Virus Corona Disease (Covid-19) di lingkungan pendidikan. Kampus sebagai salah satu lembaga pendidikan juga harus mengikuti aturan yang di keluarkan pemerintah dengan menghentikan kegiatan belajar tatap muka di kelas. Kampus Universitas Bina sara Informatika sebagai salah satu kampus swasta terkemuka di Jakarta telah mengeluarkan kebijakan untuk melakukan Pembelajaran Jarak Jauh (PJJ) selama satu semester terhitung sejak tanggal 17 Maret 2020. Kebijakan kampus tersebut tertuang dalam Surat Edaran Rektor Nomor:035/3.02/UBSI/III/2020 tanggal 11 Maret 2020.Sehingga kegiatan perkuliahan dilakukan melalui media komunikasi internet.

Kemajuan teknologi internet dalam menunjang media komunikasi dari waktu ke waktu terus mengalami kemajuan yang signifikan. Teknologi internet saat ini sudah dapat diakses melalui telepon pintar (smartphone)yang didalamnya terdapat aplikasi-aplikasi yang dapat digunakan untuk komunikasi. Beberapa aplikasi yang dapat digunakan untuk kegiatan perkuliahan adalah Whatsapp, Meeting Zoom, Line Messenger, Skype,Whatsapps, Google Class Room dan masih banyak aplikasi yang lainnya.

Kata kata kuliah, menurut Kamus Besar Bahasa Indonesia adalah pelajaran yang diberikan di perguruan tinggi atau mengikuti pelajaran di pergurun tinggi.Kegiatan kuliah di UBSIsejak 2015 sudah dilakukan dengan dua cara yaitu kuliah tatap muka di kelas dan kuliah melalui internet yang menggunakan website elearning.bsi.ac.id. Namun sejak wabah Covid 19 website tersebut tidak mampu bekerja dengan baik dikarenakan lonjakan pemakaian oleh mahasiswa UBSI berbagai jurusan yang jumlahnya 20 ribu orang, sehingga diputuskan agar dosen dan mahasiswa menggunakan media internet lain untuk kegiatan kuliah.

Tugas perguruan tinggi adalah menyelenggarakan pendidikan tinggi, menurut (PeraturanPemerintah, No. 60:2009)menyatakan bahwa pendidikan tinggi diselenggarakan melalui proses pembelajaran yang mengembangkan kemampuan 
belajar mandiri. Dan dinyatakan juga dalam penyelenggaran pendidikan tinggi dapat dilakukan kuliah, seminar, simposium, diskusi panel, lokakarya, praktikum dan kegiatan ilmiah lain. Dapat kita simpulkan bahwa Kuliah adalah salah satu kegiatan belajar yang dilakukan oleh perguruan tinggi dengan menggunakan berbagai sarana seperti ruang belajar maupun media internet.

Salah satu aplikasi media internet seperti Whatsapps telah dikenal oleh masyarakat sebagai salah satu media sosial yang paling populer dan paling banyak digunakan sehingga Whatsapps bukan lagi hal yang baru di masyarakat. Menurut Dailey dalam (Suryaningsih, 2020) media sosial adalah sebuah konten yang proses pembuatannya menggunakan teknologi penerbitan yang dapat diakses dengan mudah dan terukur. Dikarenakan kemudahan penggunan Whatsapps, di era Covid 19 saat ini Whatsapps banyak digunakan juga oleh dosen dan mahasiswa UBSI sebagai media pembelajaran (kuliah). Menurut Gagne dalam (Litianingsih, 2020), media pembelajaran adalah berbagai jenis komponen dalam lingkungan peserta didik yang dapat memotivasi peserta didik untuk belajar. Dapat disimpulkan kuliah dapat berlangsung dengan bantuan internet.

(Hamka, 2015)_mengatakan bahwa secara kata-perkata internet berarti jaringan antara atau penghubung. Dan menurut Pixy Ferris secara general medefinisikan komunikasi bermedia internet sebagai "interaksi secara interpersonal yang dihubungkan oleh komputer, yang meliputi komunikasi asynchronous dan synchronous melalui fasilitas dalam internet".

Menurut Purbo (Prihatna, 2005) Internet pada dasarnya adalah suatu media yang dipakai untuk mengefesiensikan proses komunikasi yang disambungkan lewat berbagai aplikasi semacam Web, VoIP, E-mail.

Karakteristik media internet meliputi hal-hal sebagai berikut:

a) Menciptakan pengertian dengan menulis "surat" melalui e-mail, menuliskan kata-kata pada waktu yang sama dalam komunitas chatting, serta menciptakan websites melalui penciptaan file multimedia;

b) Menyebarkan pengertian melalui komunikasi point to point (E-mail), dan komunikasi point to multi point (IRc, Web site);

c) Merasakan arti dalam teks dan multimedia pada websites, e-mail dan IRC dan Whatsapps, Meeting Zoom. 
d) Berpartisipasi dalam forum untuk awal penjelajahan karakteristik komunitas seperti tujuan bersama, norma-norma dan tradisi.

Asosiasi Penyelenggara Jasa Internet Indonesia (APJII, 2017), pada tahun 2017 jumlah pengguna internet di Indonesia mencapai 143,26 juta jiwa. Angka tersebut meningkat dibandingkan pada tahun sebelumnya yakni tahun 2016 yang tercatat mencapai 132,7 juta jiwa.Dari data tersebut dapat kita simpulkan bahwa penggunaan aplikasi Whatsapps termasuk di dalamnya.

Whatsapp (WA) merupakan aplikasi pesan instan yang terhubung pada jaringan internet yang dapat dioperasikan pada smartphone android, iphone, dan juga padakomputer. Whatsapp memiliki fungsi yang hampir sama dengan aplikasi perpesanan pada ponsel terdahulu.

Pada awal tahun 2009, aplikasi whatsapp diciptakan oleh Ian Koum seorang imigran Ukraina yang tinggal di Mountain View, California.WhatsApp menjadi aplikasi yang paling fenomenal dengan memiliki pengguna yang paling banyak di dunia, aplikasiWhatsApp mengalahkan aplikasi pesan Blackberry Messengger dan juga aplikasi pesan lainnya dalam hal jumlah pengguna terbanyak di dunia.

Fitur-fitur Unggulan WhatsApp :

a. Mengirim pesan teks

b. Mengirim foto dari galeri ataupun dari kamera

c. Mengirim video

d. Mengirimkan berkas-berkas kantor atau yang lainnya, menelpon melalui suara, termasuk mengirim pesan suara yang dapat didengarkan oleh penerima setiap saat.

e. Berbagi lokasi memanfaatkan GPS

f. Mengirimkan kartu kontak

g. WhatsApp juga mendukung beberapa emoticon, namun sedikit untuk stiker

h. Di WhatsApp, pengguna juga dapat mengatur panel profilnya sendiri, terdiri dari nama, foto, status serta beberapa alat pengaturan privasi untuk melindungi profil dan juga alat bantuan untuk membackup pesan, mengubah nomor akun dan melakukan pembayaran. 
Menurut (Nitisusastro, 2012)menjelaskan ada faktor- faktor yang bisa mempengaruhi kitadalam menggunakan suatu produk.Faktor-faktor tersebut adalah faktor pengetahuan, Faktor manfaat dan faktor penggunaan.

Kita dapat menyimpulkan bahwa produk bisa berarti macam-macam produk, disini yang kami maksud adalah whatsapp sebagai produk. UntukWhatsapps faktor-faktor yang mepengaruhi masyarakat menggunakannya diantaranya :

\section{Pengetahuan}

Tentang Karakteristik Pengetahuan tersebut meliputi segala tentang whatsapp, kemampuan bagaimana cara mendownload dan menggunakannya, serta biaya yang dipakai untuk mengaksesnya.

\section{Manfaat}

Kita harus tahu manfaat dari whatsapp itu sendiri seperti apa, keunggulan serta kelemahannya dibandingkan dengan aplikasi lainnya.

\section{Penggunaan}

Penggunaan disini lebih mengarah pada segi waktu, yaitu berapa lama whatsapp bisa digunakan jika tersambung dengan koneksi internet dan tujuan menggunakan whatsapp

Penggunaan Whatsapps secara umum telah banyak digunakan masyarakat khususnya para remaja dan mahasiswa.

Mahasiswa adalah seseorang yang sedang dalam proses menimba ilmu ataupun belajar dan terdaftar sedang menjalani pendidikan pada salah satu bentuk perguruan tinggi yang terdiri dari akademik, politeknik,sekolah tinggi, institut dan universitas (Hartaji, 2012).Dalam Kamus Bahasa Indonesia (KBBI), mahasiswa didefinisikan sebagai orang yang belajar di Perguruan Tinggi (Setiawan, 2019). Menurut (Siswoyo, 2013) mahasiswa dapat didefinisikan sebagai individu yang sedang menuntut ilmu ditingkat perguruan tinggi, baik negeri maupun swasta atau lembaga lain yang setingkat dengan perguruan tinggi. Mahasiswa dinilai memiliki tingkat intelektualitas yang tinggi, kecerdasan dalam berpikir dan kerencanaan dalam bertindak.Berpikir kritis dan bertindak dengan cepat dan tepat merupakan sifat yang cenderung melekat pada diri setiap mahasiswa, yang merupakan prinsip yang saling melengkapi. 
Menurut Kartono dalam (Siregar, 2006), mahasiswa merupakan anggota masyarakat yang mempunyai ciri-ciri tertentu, antara lain:

a. Mempunyai kemampuan dan kesempatan untuk belajar di perguruan tinggi, sehingga dapat digolongkan sebagai kaum intelektual.

b. Yang karena kesempatan di atas diharapkan nantinya dapat bertindak sebagai pemimpin yang mampu dan terampil, baik sebagai pemimpin masyarakat ataupun dalam dunia kerja.

c. Diharapkan dapat menjadi daya penggerak yang dinamis bagi proses modernisasi.

d. Diharapkan dapat memasuki dunia kerja sebagai tenaga yang berkualitas dan profesional.

Mahasiswa sebagai agen perubahan sosial selalu dituntut untuk menunjukkan peranannya dalam kehidupan nyata.Menurut (Siallagan, 2011), ada tiga peranan penting dan mendasar bagi mahasiswa yaitu intelektual, moral, sosial.

a. Peran intelektual

Mahasiswa sebagai orang yang intelek, jenius, dan jeli harus bisa menjalankan hidupnya secara proporsional, sebagai seorang mahasiswa, anak, serta harapan masyarakat.

b. Peran moral

Mahasiswa sebagai seorang yang hidup di kampus yang dikenal bebas berekpresi, beraksi, berdiskusi, berspekulasi dan berorasi, harus bisa menunjukkan perilaku yang bermoral dalam setiap tindak tanduknya tanpa terkontaminasi dan terpengaruh oleh kondisi lingkungan.

c. Peran sosial

Mahasiswa sebagai seorang yang membawa perubahan harus selalu bersinergi, berpikir kritis dan bertindak konkret yang terbingkai denga kerelaan dan keikhlasan untuk menjadi pelopor, penyampai aspirasi dan pelayan masyarakat.

Mahasiswa dalam kuliah menimba ilmu di perguruan tinggi harus didukung oleh semua pihak khususnya perguruan tinggi sehingga akan menimbulkan kepuasaan mahasiswa dimana pada akhirnya akan berperan maksimal secara 
intelektual, moral dan sosial.Kepuasaan menurut (Tjiptono, 2011)adalah persaaan senang atau kecewa seseorang yang berasal dari perbandingan antara kesannya terhadap kinerja atau hasil suatu produk dan harapan-harapannya. Menurut (Retnoningsih, 2012)kepuasan merupakan asal kata yang berarti puas merasa senang, lega, kenyang, dan sebagainya karena sudah merasai secukup-cukupnya atau sudah terpenuhi hasrat hatinya. (Sopiatin, 2010) mengatakan bahwa kepuasan mahasiswa adalah sikap positif mahasiswa terhadap pelayanan lembaga pendidikan tinggi karena adanya kesesuaian antara harapan dari pelayanan dibandingkan dengan kenyataan yang diterimanya.

Terdapat lima indikator kepuasan mahasiswa terhadap mutu pendidikan menurut Berry dan Parasuraman dalam (Alma, 2005), yaitu:

1. Keandalan, berhubungan dengan kebijakan pimpinan, kompetensi dosen dan pelayanan karyawan dalam memberikan pelayanan yang bermutu dengan yang dijanjikan, konsisten, yang sesuai dengan kebutuhan dan harapan mahasiswa.

2. Daya tanggap, kesedian personil sekolah untuk mendengarkan dan mengatasi keluhan mahasiswa/siswa yang berhubungan dengan masalah kuliah yang menyangkut masalah-masalah sekolah.

3. Kepastian, yaitu suatu keadaan di mana lembaga/sekolah memberikan jaminan kepastian layanan kepada mahasiswa yang tidak terlepas dari kemampuan personil lembaga/sekolah, terutama pimpinan, dosen dan karyawan untuk menimbulkan keyakinan dan kepercayaan terhadap janji-janji sekolah terhadap mahasiswa, disamping layanan-layanan lainnya.

4. Empati, merupakan keadaan mental yang membuat seseorang merasa dirinya di keadaan orang lain. Dengan demikian bentuk empati lembaga/sekolah terhadap kebutuhan mahasiswa adalah adanya pemahaman personil lembaga/terhadap kebutuhan mahasiswa dan berupaya kearah pencapaiannya.

5. Berwujud, dalam dunia pendidikan berhubungan dengan aspek fisik sekolah yang diperlukan untuk menunjang proses belajar mengajar, meliputi; bangunan, kebersihan lingkungan, taman, laboratorium, perpustakaan dan lainya (Sopiatin, 2010). 


\section{METODE}

Dalam penelitian ini metode penelitian yang digunakan adalah metode penelitian kuantitatif. Dalam pengumpulan data penulis lakukan melalui pengamatan (observasi), studi pustaka dan serta penyebaran angket/ kuesioner kepada mahasiswa UBSI Jakarta. Akan tetapi dengan diberlakukannya jaga jarak sosial (social distancing), maka kami akan melakukan penyebaran kuesioner melalui email, whatsapps group, atau pun media sosial lainnya. Waktu penelitian dilakukan selama 4 bulan dari bulan Februari 2020 hingga Mei 2020.

Variabel penelitian, menurut (Sugiyono, 2014)variabel penelitian adalah suatu atribut atau sifat atau nilai dari orang, obyek, atau kegiatan yang mempunyai variasi tertentu yang ditetapkan oleh peneliti untuk dipelajari dan kemudian ditarik kesimpulannya.Ada 2 jenis variabel yaitu variabel dependen dan variabel independen. Menurut (Widiyanto, 2013)bahwa variabel dependen adalah variabel yang keberadaanya dipengaruhi oleh variabel lain. Sedangkan variabel Independen menurut Sugiyono dalam (Zulfikar, 2016)adalah variabel yang menjadi penyebab adanya atau timbulnya perubahan variabel dependen, atau disebut juga sebagai variabel yang mempengaruhi. Hal senada juga dikemukakan oleh (Widiyanto, 2013)bahwa variabel independen adalah variabel yang mepengaruhi variabel lain.

Variabel Independen dalam penelitian ini adalah :

$\mathrm{X}=$ Kuliah melalui Whatsapps

Variabel Dependen dalam penelitin ini adalah :

$\mathrm{Y}=$ Kepuasaan mahasiswa

Persamaan regresi sedrhana adalah $\mathrm{Y}=\mathrm{X}+\mathrm{c}$

Kerangka penelitian adalah sebagai berikut:

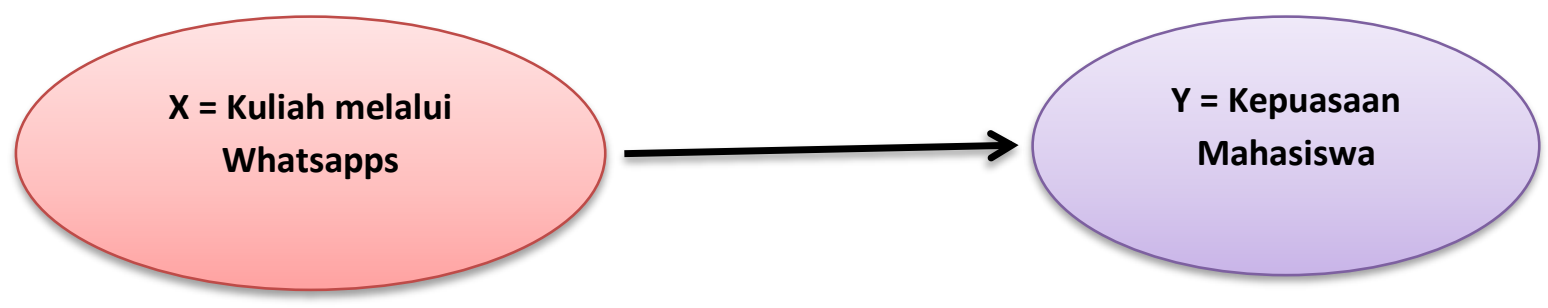


Rumusan Hipotesis:

H0 = Tidak ada pengaruh kuliah melalui Whatsapps terhadap kepuasaan mahasiswa

H1 = Ada pengaruh kuliah melalui Whatsapps terhadap kepuasaan mahasiswa

Kisi-Kisi Operasional Variabel X (Kuliah melalui Whatsapps)

\begin{tabular}{lc}
\hline \multicolumn{1}{c}{ Dimensi } & Indikator \\
1.Pengetahuan & 3 \\
2. Manfaat & 3 \\
3. Penggunan & 2 \\
Total & 8 \\
\hline
\end{tabular}

Kisi-Kisi Operasional Variabel Y (Kepuasaan Mahasisw)

\begin{tabular}{lc}
\hline \multicolumn{1}{c}{ Dimensi } & Indikator \\
1.Keandalan & 3 \\
2.Daya tanggap & 2 \\
3. Penggunan & 2 \\
4. Empati & 3 \\
5. Berwujud & 2 \\
Total & 12 \\
\hline
\end{tabular}

Jawaban Survey menggunakan skala likert 1 sampai dengan 5, dimana 1 = Sangat tidak setuju, 2 = Kurang setuju, 3 = Tidak setuju, 4 = Setuju, 5 = Sangat setuju. Hasil dari pengumpulan data kuesioner diolah dengan menggunakan program SPSS 19

\section{HASIL DAN PEMBAHASAN}

Populasi mahasiswa D3 Manajemen Pajak UBSI Cabang salemba 22 Jakarta keseluruhan berjumlah 160 mahasiswa dengan jumlah menurut jenis kelamin sebagai berikut:

\section{Tabel Populasi Mahasiswa D3 Manajamen Pajak} UBSI Cabang Salemba 22 Jakarta

\begin{tabular}{lcc}
\hline \multicolumn{2}{c}{ Jenis Kelamin } & Jumlah \\
\hline Laki-laki & 77 \\
Wanita & & 83 \\
& Total & $\mathbf{1 6 0}$ \\
\hline
\end{tabular}




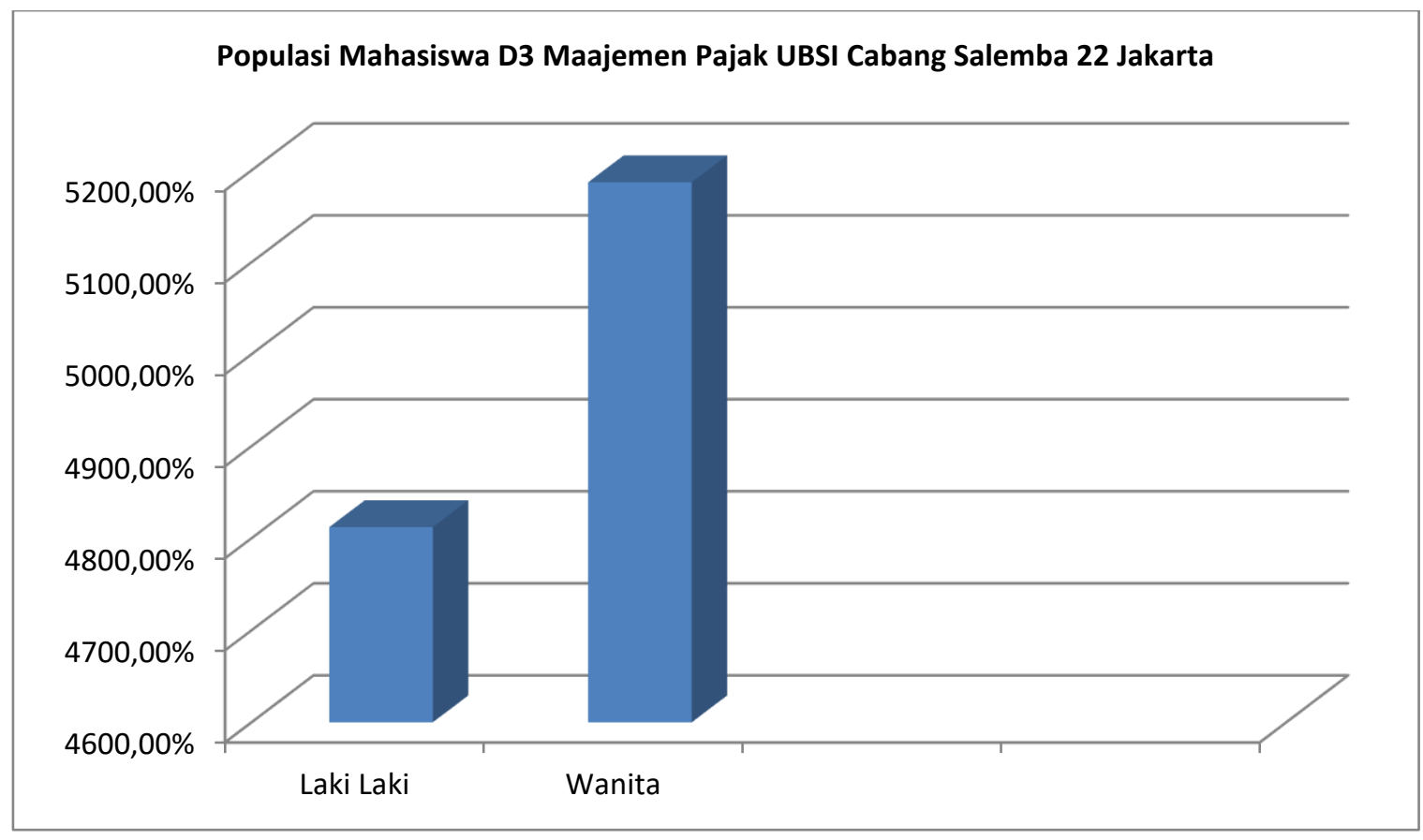

Sumber Kampus UBSI Salemba 22 Jakarta

Diagram Populasi Mahasiswa D3 Manajemen Pajak UBSI Cabang Salemba 22 Jakarta

Jumlah Mahasiswa laki-laki sebanyak 48,12 \%

Jumlah Mahasiswa Wanita sebanyak 51,87\%'

Dari populasi tersebut dapat kita ambil sample menggunakan rumus Slovin sebagai berikut:

$$
\begin{aligned}
& \text { Rumus Slovin }=\quad \mathrm{n}=\frac{\mathrm{N}}{1+\mathrm{N} \cdot \mathrm{e}^{2}} \\
& \mathrm{~N}=\text { Jumlah Populasi } \\
& \mathrm{n}=\text { Jumlah sample } \\
& \mathrm{e}=\text { Batas Toleransi kesalahan }(10 \%)
\end{aligned}
$$


160

Sample $=\mathrm{n}=\longleftarrow=61,53$ dibulatkan 62

Mahasiswa

$$
1+(160) \cdot(0,1)^{2}
$$

\section{Uji Validitas}

Validitas menurut (Arikunto, 2006)adalah nilai yang menunjukkan kesahihan suatu data dalam instrumen penelitian. Data $r$ tabel dengan rumus df $=\mathrm{N}-2$ dengan uji satu arah tingkat signifikansi 0,05 dimana $\mathrm{N}=$ 62diketemukan angka pada $\mathrm{r}$ tabel sebesar 0,2108. Maka apabila $\mathrm{r}$ hitung data $\mathrm{X}$ dan data $\mathrm{Y}$ lebih besar dari pada $\mathrm{r}$ tabel maka data tersebut kita katakan $\mathrm{X}$ dan $\mathrm{Y}$ adalah valid. Dan $\mathrm{r}$ hitung diolah dengan menggunakan program statistik SPSS 19.

Dari hasil pengolahan data X dengan SPSS 19 , didapat hasil $r$ hitung melebihi dari $r$ tabel $(0,2108)$. Dengan demikian dapat kita katakan bahwa data $\mathrm{X}$ (Kuliah melalui Whatsapps) adalah Valid. Berikut Tabel hasil $\mathrm{r}$ hitung data X di bawah ini:

Tabel r hitung Data X (Kuliah melalui Whatsapps)

\begin{tabular}{|c|c|c|c|c|c|c|c|c|c|}
\hline & & \multicolumn{5}{|c|}{ Correlations } & \multirow{3}{*}{$\begin{array}{c}\text { PER_ } \\
6\end{array}$} & \multirow{3}{*}{$\begin{array}{c}\text { PER_ } \\
7\end{array}$} & \multirow{3}{*}{ PER_8 } \\
\hline & & PER_ & PER_ & PER_ & PER_ & PER_ & & & \\
\hline & & 1 & 2 & 3 & 4 & 5 & & & \\
\hline \multirow[t]{3}{*}{ PER_1 } & Pearson Correlation & 1 & ,157 & 093 & , 147 &,- 022 & ,131 &,- 005 & ,230 \\
\hline & Sig. (2-tailed) & & ,224 & ,473 & ,254 & ,866 & ,309 & ,969 & 072 \\
\hline & $\mathrm{N}$ & 62 & 62 & 62 & 62 & 62 & 62 & 62 & 62 \\
\hline \multirow[t]{3}{*}{ PER_2 } & Pearson Correlation & ,157 & 1 &,- 006 &,- 064 &,- 039 &,- 098 &,- 043 & ,230 \\
\hline & Sig. (2-tailed) & ,224 & & ,960 & 619 & ,766 & ,449 & ,738 & 072 \\
\hline & $\mathrm{N}$ & 62 & 62 & 62 & 62 & 62 & 62 & 62 & 62 \\
\hline \multirow[t]{3}{*}{ PER_3 } & Pearson Correlation & ,093 &,- 006 & 1 &,- 051 &, 014 & ,038 &,$- 258^{*}$ & ,217 \\
\hline & Sig. (2-tailed) & ,473 & ,960 & & ,691 & ,915 & ,770 & ,043 & ,090 \\
\hline & $\mathrm{N}$ & 62 & 62 & 62 & 62 & 62 & 62 & 62 & 62 \\
\hline \multirow[t]{3}{*}{ PER_4 } & Pearson Correlation & 147 &,- 064 &,- 051 & 1 & 157 & 131 & ,162 & ,218 \\
\hline & Sig. (2-tailed) & ,254 & 619 & 691 & & ,223 & ,311 & ,208 & 089 \\
\hline & $\mathrm{N}$ & 62 & 62 & 62 & 62 & 62 & 62 & 62 & 62 \\
\hline \multirow[t]{3}{*}{ PER_5 } & Pearson Correlation &,- 022 &,- 039 &, 014 & 157 & 1 & , 106 & 163 & ,212 \\
\hline & Sig. (2-tailed) & ,866 & ,766 & ,915 & ,223 & & ,414 & ,207 & ,098 \\
\hline & $\mathrm{N}$ & 62 & 62 & 62 & 62 & 62 & 62 & 62 & 62 \\
\hline PER_6 & Pearson Correlation & ,131 &,- 098 & 038 & 131 & ,106 & 1 &,- 020 & ,227 \\
\hline
\end{tabular}




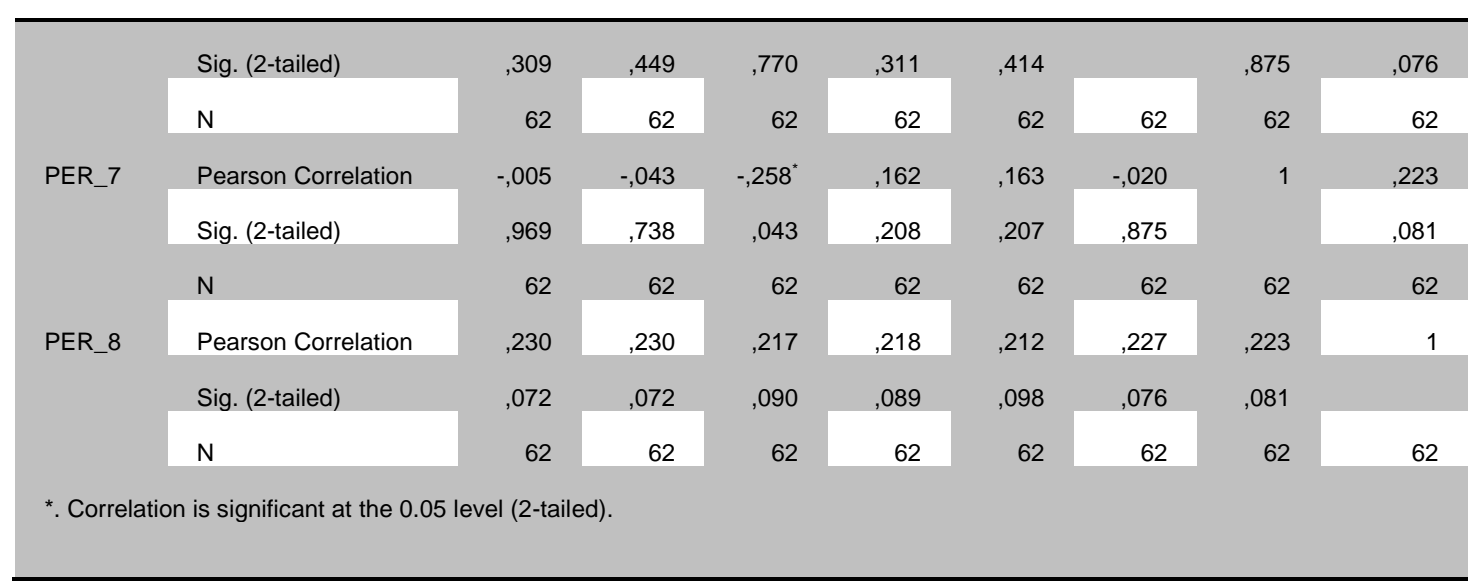

Dari hasil pengolahan data Y dengan SPSS 19 , didapat hasil $\mathrm{r}$ hitung melebihi dari $r$ tabel $(0,2108)$. Dengan demikian dapat kita katakan bahwa data $\mathrm{Y}$ (Kepuasaan mahasiswa) adalah Valid. Berikut Tabel hasil $r$ hitung data Y di bawah ini:

Tabel $\mathbf{r}$ hitung Data Y (Kepuasaan Mahasiswa)

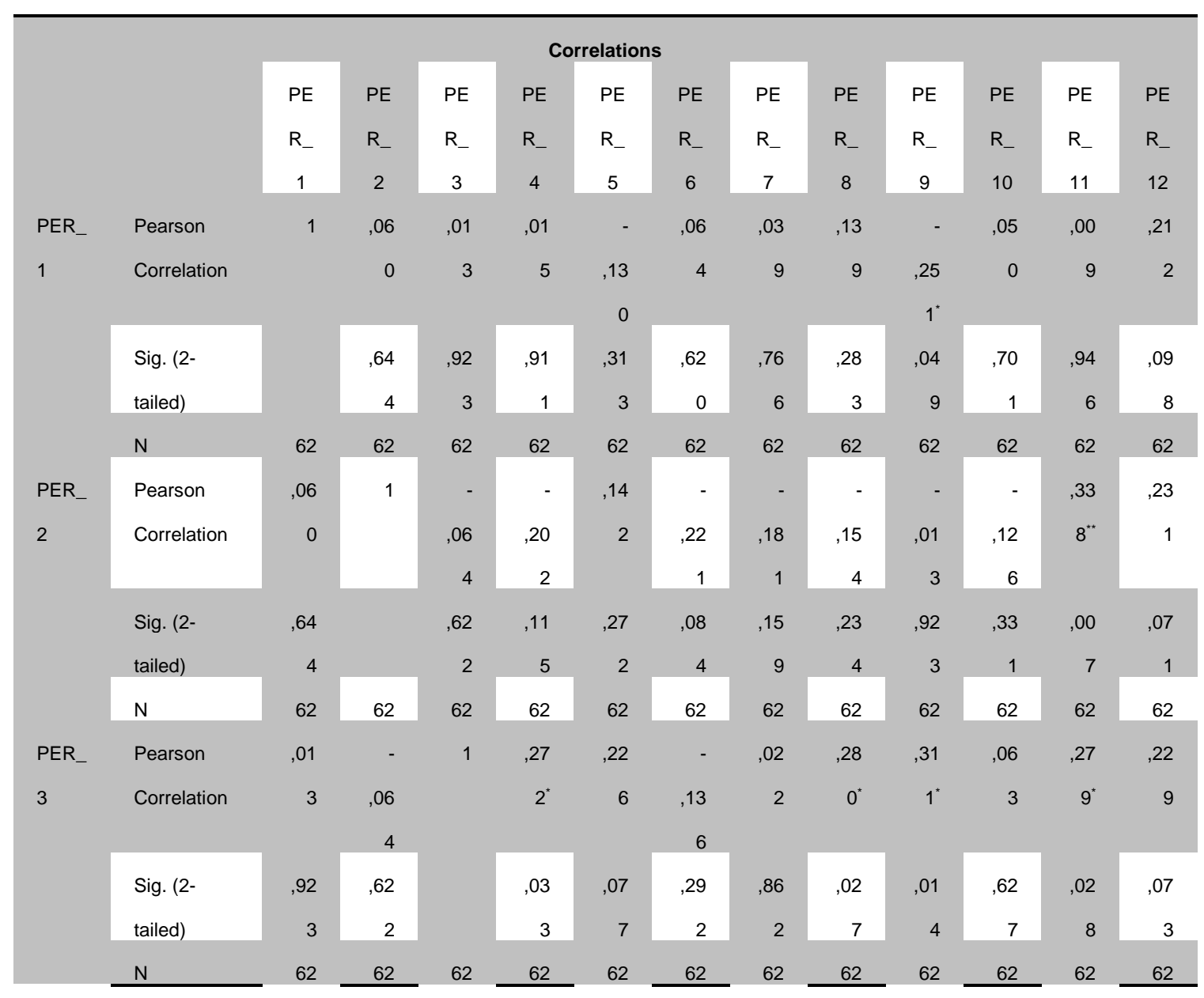




\begin{tabular}{|c|c|c|c|c|c|c|c|c|c|c|c|c|c|}
\hline PER_ & Pearson & ,01 & - & ,27 & 1 & 38 & ,06 & ,17 & ,33 & ,29 & 21 & - & ,22 \\
\hline \multirow[t]{4}{*}{4} & Correlation & 5 & ,20 & $2^{*}$ & & $2^{* *}$ & 4 & 5 & $3^{* *}$ & $2^{*}$ & 0 & ,02 & 6 \\
\hline & Sig. (2- & ,91 &, 11 &, 03 & &, 00 & ,62 &, 17 &, 00 & ,02 & , 10 & ,82 &, 07 \\
\hline & tailed) & 1 & 5 & 3 & & 2 & 1 & 5 & 8 & 1 & 1 & 9 & 7 \\
\hline & N & 62 & 62 & 62 & 62 & 62 & 62 & 62 & 62 & 62 & 62 & 62 & 62 \\
\hline PER & Pearson & - &, 14 & ,22 & ,38 & 1 & - & ,09 & ,16 &, 26 & ,34 & ,16 & ,22 \\
\hline \multirow[t]{4}{*}{5} & Correlation & ,13 & 2 & 6 & $2^{* *}$ & & ,14 & 9 & 2 & $0^{*}$ & $8^{* *}$ & 8 & 6 \\
\hline & Sig. (2- &, 31 & ,27 &, 07 & ,00 & &, 26 & ,44 & ,20 &, 04 & , 00 & ,19 & ,07 \\
\hline & tailed) & 3 & 2 & 7 & 2 & & 6 & 3 & 7 & 1 & 6 & 2 & 7 \\
\hline & N & 62 & 62 & 62 & 62 & 62 & 62 & 62 & 62 & 62 & 62 & 62 & 62 \\
\hline PER & Pearson & ,06 & - & - &, 06 & - & 1 &, 04 & ,42 &, 10 &, 32 & - & ,22 \\
\hline \multirow[t]{5}{*}{6} & Correlation & 4 & ,22 & ,13 & 4 & ,14 & & 0 & $9^{* *}$ & 7 & $2^{*}$ & ,13 & 1 \\
\hline & & & 1 & 6 & & 3 & & & & & & 9 & \\
\hline & Sig. (2- & ,62 & ,08 &, 29 & ,62 & ,26 & & ,75 &, 00 &, 40 & ,01 & ,28 &, 08 \\
\hline & tailed) & 0 & 4 & 2 & 1 & 6 & & 8 & 1 & 8 & 1 & 2 & 4 \\
\hline & N & 62 & 62 & 62 & 62 & 62 & 62 & 62 & 62 & 62 & 62 & 62 & 62 \\
\hline PER_ & Pearson & ,03 & - &, 02 & ,17 &, 09 &, 04 & 1 & ,02 & - & - & - & ,21 \\
\hline \multirow[t]{5}{*}{7} & Correlation & 9 &, 18 & 2 & 5 & 9 & 0 & & 4 &, 33 & ,06 &, 01 & 3 \\
\hline & & & 1 & & & & & & & $4^{* *}$ & 4 & 9 & \\
\hline & Sig. (2- & ,76 & ,15 & ,86 &, 17 &, 44 &, 75 & & 85 &, 00 & ,62 & 88 & ,09 \\
\hline & tailed) & 6 & 9 & 2 & 5 & 3 & 8 & & 0 & 8 & 1 & 3 & 6 \\
\hline & N & 62 & 62 & 62 & 62 & 62 & 62 & 62 & 62 & 62 & 62 & 62 & 62 \\
\hline PER_ & Pearson & , 13 & - & ,28 & ,33 & ,16 & ,42 & ,02 & 1 & ,33 &, 30 & - & ,22 \\
\hline \multirow[t]{5}{*}{8} & Correlation & 9 &, 15 & $0^{*}$ & $3^{* *}$ & 2 & $9^{* *}$ & 4 & & $9^{* *}$ & $5^{*}$ & ,03 & 6 \\
\hline & & & & & & & & & & & & & \\
\hline & Sig. (2- & ,28 & ,23 &, 02 &, 00 & ,20 &, 00 & ,85 & &, 00 &, 01 & ,81 &, 07 \\
\hline & tailed) & 3 & 4 & 7 & 8 & 7 & 1 & 0 & & 7 & 6 & 9 & 8 \\
\hline & N & 62 & 62 & 62 & 62 & 62 & 62 & 62 & 62 & 62 & 62 & 62 & 62 \\
\hline PER & Pearson & - & - &, 31 & ,29 & ,26 & ,10 & - & ,33 & 1 & ,14 & ,09 & ,22 \\
\hline \multirow[t]{5}{*}{9} & Correlation & ,25 &, 01 & $1^{*}$ & $2^{*}$ & $0^{*}$ & 7 & ,33 & $9^{* *}$ & & 6 & 8 & 4 \\
\hline & & $1^{*}$ & 3 & & & & & $4^{* *}$ & & & & & \\
\hline & Sig. (2- & ,04 &, 92 &, 01 &, 02 & ,04 &, 40 &, 00 & ,00 & &, 25 & ,44 & ,08 \\
\hline & tailed) & 9 & 3 & 4 & 1 & 1 & 8 & 8 & 7 & & 8 & 7 & 1 \\
\hline & N & 62 & 62 & 62 & 62 & 62 & 62 & 62 & 62 & 62 & 62 & 62 & 62 \\
\hline PER & Pearson & ,05 & - &, 06 &, 21 & ,34 &, 32 & - &, 30 &, 14 & 1 & - & ,22 \\
\hline \multirow[t]{4}{*}{10} & Correlation & 0 &, 12 & 3 & 0 & $8^{* *}$ & $2^{*}$ & ,06 & $5^{*}$ & 6 & &, 00 & 9 \\
\hline & & & 6 & & & & & 4 & & & & 7 & \\
\hline & Sig. (2- & ,70 &, 33 &, 62 & ,10 &, 00 &, 01 & ,62 &, 01 & ,25 & & ,95 &, 07 \\
\hline & tailed) & 1 & 1 & 7 & 1 & 6 & 1 & 1 & 6 & 8 & & 4 & 4 \\
\hline
\end{tabular}




\begin{tabular}{|c|c|c|c|c|c|c|c|c|c|c|c|c|c|}
\hline & $\mathrm{N}$ & 62 & 62 & 62 & 62 & 62 & 62 & 62 & 62 & 62 & 62 & 62 & 62 \\
\hline $\mathrm{PER}_{-}$ & Pearson &, 00 &, 33 &, 27 & - & ,16 & - & - & - & ,09 & - & 1 & ,23 \\
\hline \multirow[t]{5}{*}{11} & Correlation & 9 & $8^{* *}$ & $9^{*}$ & ,02 & 8 & ,13 & ,01 & ,03 & 8 & ,00 & & 8 \\
\hline & & & & & 8 & & 9 & 9 & 0 & & 7 & & \\
\hline & Sig. (2- & ,94 &, 00 &, 02 & ,82 & ,19 & ,28 & ,88 &, 81 & ,44 & ,95 & & ,06 \\
\hline & tailed) & 6 & 7 & 8 & 9 & 2 & 2 & 3 & 9 & 7 & 4 & & 2 \\
\hline & $\mathrm{N}$ & 62 & 62 & 62 & 62 & 62 & 62 & 62 & 62 & 62 & 62 & 62 & 62 \\
\hline \multirow{5}{*}{$\begin{array}{l}\text { PER } \\
12\end{array}$} & Pearson & ,21 & ,23 & ,22 & ,22 & ,22 & ,22 & ,21 & ,22 & ,22 & ,22 & ,23 & 1 \\
\hline & Correlation & 2 & 1 & 9 & 6 & 6 & 1 & 3 & 6 & 4 & 9 & 8 & \\
\hline & Sig. (2- & ,09 & ,07 & ,07 & ,07 & ,07 & ,08 & ,09 & ,07 & ,08 & ,07 & ,06 & \\
\hline & tailed) & 8 & 1 & 3 & 7 & 7 & 4 & 6 & 8 & 1 & 4 & 2 & \\
\hline & $\mathrm{N}$ & 62 & 62 & 62 & 62 & 62 & 62 & 62 & 62 & 62 & 62 & 62 & 62 \\
\hline
\end{tabular}

\section{Uji Reliabilitas}

Reliabilitas adalah ketepatan alat ukur yang digunakan dalam penelitian. Alat ukur disini adalah kuesioner. Menurut(Sugiyono2014) reliabilitas instrumen adalah ketepatan alat ukur yang digunakan beberapa kali dalam mengukur objek yang sama maka akan menghasilkan data yang sama. Dan dari hasil uji reliabilitas data $\mathrm{X}$ (Kuliah melalui Whatsapps) didapatkan hasil sebagai berikut :

\begin{tabular}{ll}
\hline Reliability Statistics & \\
Cronbach's Alpha & N of Items \\
, 420 & 8 \\
\hline
\end{tabular}

\begin{tabular}{|c|c|c|c|c|}
\hline \multicolumn{5}{|c|}{ Item-Total Statistics } \\
\hline & $\begin{array}{l}\text { Scale Mean if } \\
\text { Item Deleted }\end{array}$ & $\begin{array}{l}\text { Scale Variance } \\
\text { if Item Deleted }\end{array}$ & $\begin{array}{l}\text { Corrected } \\
\text { Item-Total } \\
\text { Correlation }\end{array}$ & $\begin{array}{l}\text { Cronbach's } \\
\text { Alpha if Item } \\
\text { Deleted }\end{array}$ \\
\hline PER_1 & 30,53 & 4,745 & ,217 & ,370 \\
\hline PER_2 & 30,52 & 5,500 & ,044 & ,439 \\
\hline PER_3 & 30,35 & 5,643 & ,001 & ,453 \\
\hline PER_4 & 30,34 & 4,916 & 241 & 363 \\
\hline PER_5 & 30,53 & 4,909 & 195 & 381 \\
\hline PER_6 & 30,34 & 4,982 & 160 & 397 \\
\hline PER_7 & 30,68 & 4,911 & ,083 & ,446 \\
\hline PER_8 & 30,35 & 3,938 &, 531 & ,202 \\
\hline
\end{tabular}

Bila kita melihat angka $r$ tabel pada $\mathrm{N}=62$ dan tingkat sinifikansi 0,05 didapat angka $=0,2108$, maka hasil dari perhitungan reliabilitas Pernyataan 1 sampai dengan Pernyataan 8 angkanya di atas $r$ tabel, dan angka cronbach's alpha 
sebesar 0,420, jadi dapat kita simpulkan bahwa alat ukur atau kuesioner Kuliah melalui Whatsapps (X) dalam penelitian ini adalah Reliabel.

Dan dari hasil uji reliabilitas data Y (Kepuasaan mahasiswa) didapatkan hasil angka cronbach's alpha sebesar 0,580 yang melebihi dari pada angka $r$ tabel, dimana angka $r$ tabel adalah 0,2108. Sehingga kita dapat menyimpulkan alat ukur atau kuesioner tentang Kepuasaan mahasiswa (Y) adalah Reliabel.

\begin{tabular}{ll}
\hline Reliability Statistics & \\
Cronbach's Alpha & N of Items \\
580 & 12 \\
\hline
\end{tabular}

\begin{tabular}{|c|c|c|c|c|}
\hline & & Item-Total Stat & & \\
\hline & $\begin{array}{l}\text { Scale Mean if } \\
\text { Item Deleted }\end{array}$ & $\begin{array}{l}\text { Scale Variance } \\
\text { if Item Deleted }\end{array}$ & $\begin{array}{l}\text { Corrected } \\
\text { Item-Total } \\
\text { Correlation }\end{array}$ & $\begin{array}{l}\text { Cronbach's } \\
\text { Alpha if Item } \\
\text { Deleted }\end{array}$ \\
\hline PER_1 & 48,13 & 9,918 & 033 & ,599 \\
\hline PER_2 & 48,48 & 10,221 &,- 032 & ,606 \\
\hline PER_3 & 48,55 & 8,809 & ,340 & ,538 \\
\hline PER_4 & 48,37 & 8,008 & ,387 &, 519 \\
\hline PER_5 & 48,50 & 8,320 & ,387 &, 522 \\
\hline PER_6 & 48,10 & 9,663 &, 104 &, 585 \\
\hline PER_7 & 48,18 & 9,755 & ,019 & ,613 \\
\hline PER_8 & 48,05 & 8,637 & ,445 &, 519 \\
\hline PER_9 & 48,27 & 9,055 & ,243 & ,558 \\
\hline PER_10 & 48,11 & 9,184 & ,314 & ,547 \\
\hline PER_11 & 48,27 & 9,120 & , 179 & ,574 \\
\hline PER_12 & 48,26 & 8,096 &, 550 & ,490 \\
\hline
\end{tabular}

Uji regresi sederhana adalah untuk menguji variabel bebas yaitu X (Kuliah melalui Whatsapps) terhadap variabel terikat yaitu Y (Kepuasaan Mahasiswa). Jika $t$ hitung lebih besar dari t tabel, maka dapat dikatakan bahwa variabel bebas $\mathrm{X}$ berpengaruh terhadap variabel terikat $\mathrm{Y}$.

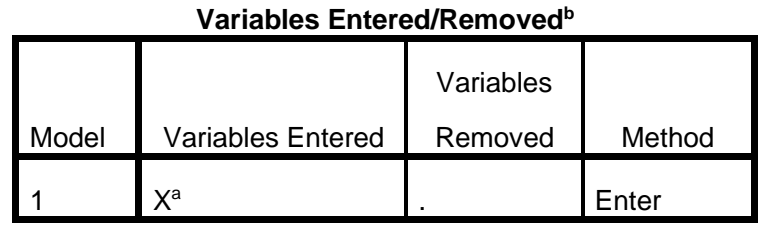
a. All requested variables entered.
b. Dependent Variable: $Y$ 
Tabel di atas variabel enter/ remove menjelaskan bahwa variabel yang dimasukan atau dibuang adalah variabel nilai trust (data $\mathrm{X}$ ) sebagai predictor danmetode yang digunakan adalah metode enter.

\begin{tabular}{|c|c|c|c|c|}
\hline & \multirow[b]{2}{*}{$\mathrm{R}$} & \multicolumn{2}{|c|}{ Model Summary } & \multirow[b]{2}{*}{$\begin{array}{l}\text { Std. Error of } \\
\text { the Estimate }\end{array}$} \\
\hline Mode & & $\begin{array}{c}\mathrm{R} \\
\text { Square }\end{array}$ & $\begin{array}{c}\text { Adjusted R } \\
\text { Square }\end{array}$ & \\
\hline 1 &, $298^{a}$ & ,089 & 073 & 3,103 \\
\hline \multicolumn{5}{|c|}{ a. Predictors: (Constant), X } \\
\hline
\end{tabular}

Dari tabel diatas dapat dijelaskan bahwa besarnya nilai hubungan/ korelasi (R) antara varibel $\mathrm{X}$ dan variabel $\mathrm{Y}$ sebesar 0,298. Menurut (Jonathan, 2006)bahwa nilai koefisien korelasi (R) memiliki tingkatan yaitu :

$\mathrm{R}=0$ artinya antara variabel $\mathrm{X}$ dan $\mathrm{Y}$ tidak mepunyai korelasi (hubungan) 0,00 sd 0,25 korelasi variabel $\mathrm{X}$ dan $\mathrm{Y}$ sangat lemah

0,25 sd 0,50 korelasi variabel $\mathrm{X}$ dan Y cukup

0,50 sd 0,75 korelasi variabel $\mathrm{X}$ dan Y kuat

0,75 sd 0,99 korelasi variabel $\mathrm{X}$ dan $\mathrm{Y}$ sangat kuat

Maka R sebesar 0,298 dapat diartikan bahwa variabel Kuliah melalui Whatsapps (X) memiliki Hubungan cukup kuat terhadap Kepuasaan Mahasiswa (Y).

Dan besarnya pengaruh variabel $\mathrm{X}$ terhadap variabel $\mathrm{Y}$ ditunjukkan dengan koefisien determinasi $\left(\mathrm{R}^{2}\right)$ merupakan pengkuadratan dari nilai $\mathrm{R}$, yang artinya nilai 0,89 merupakan nilai pengaruh variabel Trust sangat kuat terhadap variabel terikat (partisipasi), sehingga kita katakan Kuliah melalu Whatsapps mempengaruhi Kepuasaan Mahasiswa sebesar 89,0\% dan 11\% dipengaruhi variabel lain.

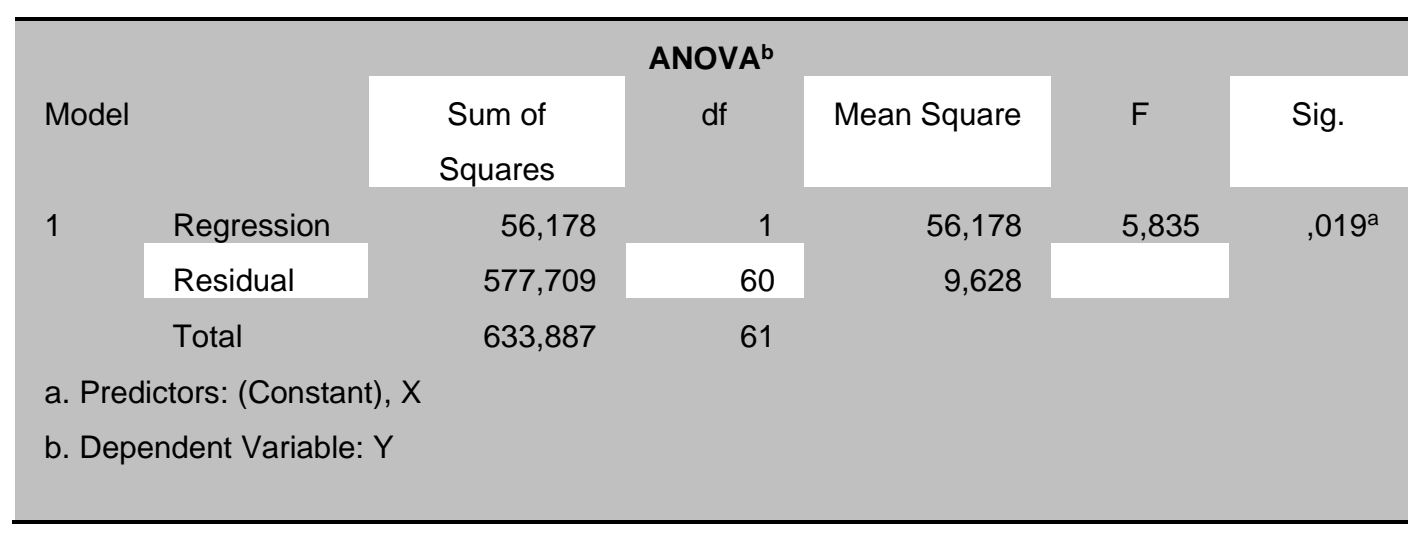


Dari tabel Anova menggambarkan bahwa apakah ada pengaruh variabel Trust $(\mathrm{X})$ terhadap variabel partisipasi (Y), dengan nilai $\mathrm{F}$ hitung 5,835 dengan tingkat signifikansi sebesar 0,019, dimana tingkat signifikansi ini berada dibawah 0,05 yang artinya signifikan. Sehingga dapat kita katakan ada pengaruh variabel $\mathrm{X}$ terhadap variabel $\mathrm{Y}$ dan model regresi ini dapat dipakai untuk memprediksi

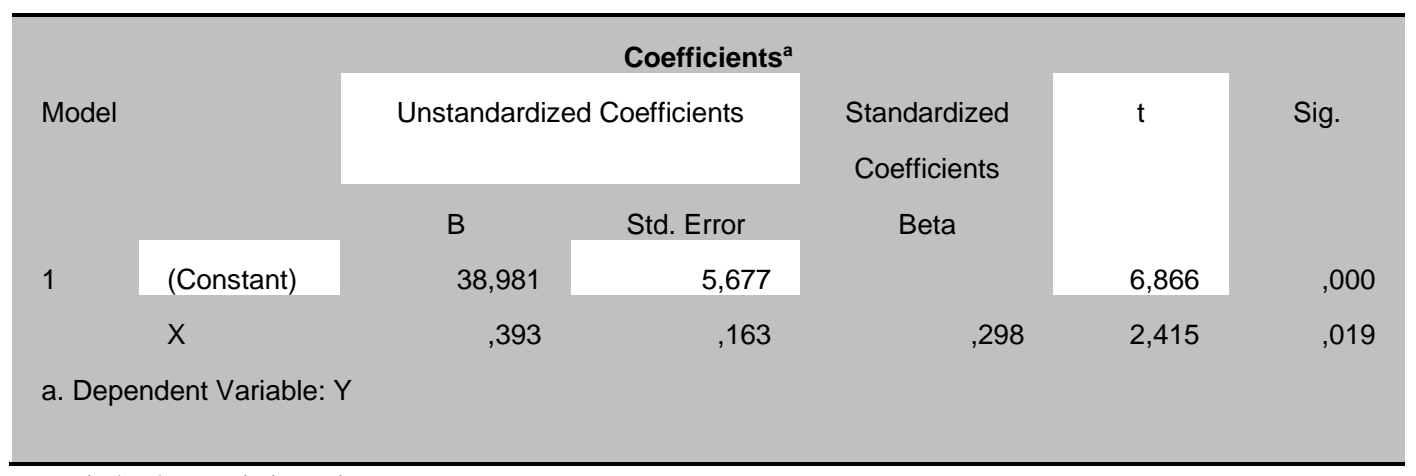

variabel partisipasi.

Dari tabel Coefficients dapat dijelaskan bahwa persamaan regresi sederhananya adalah:

$$
\mathrm{Y}=0,393 \mathrm{X}+38,981
$$

Dari persamaan regresi di atas dapat disimpulkan bahwa:

a. Apabila tidak ada kuliah melalui Whatsapps maka masih ada kepuasaan mahasiswa sebesar 38,981.

b. Setiap penambahan satu frekuensi kuliah melalui Whatsapps maka menambah kepuasaan mahasiswa sebesar 0,393.

Nilai Uji t adalah 2,415 dengan tingkat signifikansi 0,019 artinya bahwa ada pengaruh nyata antara variabel $\mathrm{X}$ terhadap Variabel Y sehingga dapat disimpulkan H0 ditolak dan H1 diterima, artinya bahwa ada Pengaruh Kuliah Melalui Whatsapps Terhadap Kepuasaan Mahasiswa D3 Manajemen Perpajakan Universitas Bina Sara Informatika (UBSI) Cabang Salemba 22 Jakarta.

\section{SIMPULAN}

Bahwa kuliah melalui Whatsapps menjadi andalan dan pilihan utama mahasiswa dikarenakan sederhana dalam pengoperasiannya, dan dapat mengirim materi pembelajaran baik dalam bentuk file dokumen, suara, gambar maupun video. Sehingga pembelajaran materi kuliah dapat tersampaikan dengan jelas di 
mahasiswa, karena mahasiswa dapat bertanya atau memberikan tanggapan kepada dosennya baik melalui chatting/ pesan teks, pesan suara (voice note), pesan video (rekaman video). Disamping itu penggunan aplikasi Whatsapps berjam-jam atau seharian sangat hemat biaya dibanding dengan aplikasi lain seperti meeting zoom yang mahal dan sangat terbatas waktunya apabila mengingikan yang gratis. Faktor lain $11 \%$ yang mempengaruhi kepuasaan mahasiswa adalah faktor waktu interaksi belajar dalam hal tanya jawab mahasiswa kepada dosennya dapat dilakukan 24 jam, dan juga faktor sinyal atau jaringan internet yang memadai serta tipe smartphone yang semakin canggih.

\section{DAFTAR RUJUKAN}

Alma, B. ( 2005). Manajemen Pemasaran dan Pemasaran Jasa. Edisi 2. Bandung: ALFABETA.

APJII, A. P. (2017). Profil Pengguna Internet Indonesia. Jakarta: Asosiasi Penyelenggara Jasa Internet Indonesia.

Arikunto, S. (2006). Prosedur Penelitian Suatu Pendekatan Praktik (Edisi Revisi VI). Jakarta: PT Rineka cipta.

Hamka, L. A. (2015). Keefektifan Penerapan Model Pembelajaran Langsung pada Materi Sistem Gerak di SMA Negeri 1 Donri-Donri. Jurnal Bionature Vol 16 No. 1 April , 58-64.

Hartaji, D. A. (2012). Motivasi Berprestasi Pada Mahasiswa yang Berkuliah Dengan jurusan pilihan orang tua. Fakultas Psikolog Universitas Gunadarma.

Jonathan, S. (2006). Metode Penelitian Kuantitatif dan Kualitatif. Yogyakarta: Graha Ilmu.

Kebudayaan, K. P. (2020, 03). Retrieved 07 03, 2020, from kemendikbud.go.id: https://www.kemdikbud.go.id/main/blog/2020/03/surat-edaranpencegahan-covid19-pada satuan-pendidikan

Liptianingsih, D. \&. (2020). Pengaruh Media Pembelajaran Terhadap Hasil Belajar Peserta Didik Kelas VII Mata Pelajaran IPS Di MTS Nereri 1 Situbondo Semseter Genap Tahun Pelajaran 2018/2019. Jurnal Pendidikan dan Kewirausahaan, 25-32.

Nitisusastro, M. (2012). Perilaku Konsumen. Bandung (ID): Alfabeta.

Parawie, s. (2016, 08 14). Retrieved 07 03, 2020, from wordpress.com: https://www.google.co.id/amp/s/sahrulparawie.wordpress.com/2016/08/1 4/makalah-tentang-whatsapp/amp/

PeraturanPemerintah. (No. 60:2009). Peraturan pemerintah Republik Indonesia. Retrieved $06 \quad 03, \quad 2020$, from kemeneng.go.id: http://simpuh.kemenag.go.id/regulasi/pp_60_99.pdf

Prihatna, H. (2005). Kiat Praktis Menjadi Webmaster Profesional. Jakarta. Jakarta: PT. Elex Media Komputindo.

Retnoningsih, S. d. (2012). Kamus Besar Bahasa Indonesia. Semarang: CV. Widya.

Setiawan, E. (2019). KBBI Online. Retrieved 07 03, 2020, from https://kbbi.web.id/kuliah 
Siallagan, D. (2011). Fungsi dan Peranan Mahasiswa. Bengkulu: UNIB.

Siregar, A. (2006). Manajemen Sumber Daya Manusia. Malang: UMM Press.

Siswoyo, D. d. (2013). Ilmu Pendidikan. Yogyakarta: UNY Press.

Sopiatin, P. (2010). Manajemen Belajar Berbasis Kepuasan Siswa. Bogor: Ghalia Indonesia.

Sugiyono. (2014). Metode Penelitian Kuantitatif, Kualitatif dan R\&D. Bandung: Alfabeta.

Suryaningsih, A. (2020). Dampak Media Sosial Terhadap Prestasi Belajar Peserta Didik. Edusaintek: Jurnal Pendidikan Sains dan Teknologi , 1-10.

Tjiptono, F. ( 2011). Service Management Mewujudkan Layanan Prima edisi 2. Yogyakarta: Andi.

Widiyanto, M. (2013). Statistika Terapan, Konsep dan Aplikasi SPSS/Lisrel dalam Penelitia Pendidikan, Psikologi dan Ilmu Sosial Lainya. Jakarta : PT Elex Media Komputindo.

Zulfikar. (2016). Pengantar Pasar Modal Dengan Pendekatan Statistika Edisi Pertama, Cetakan Pertama. Yogyakarta: Gramedia. 